\author{
ФЕЙЧЕР Оксана Олександрівна, \\ аспірант, \\ Національна академія керівних кадрів культури і мистецтв, \\ Київ, Україна, feicher@i.ua \\ ORCID ID: https://orcid.org/0000-0003-3608-3111
}

\title{
ЗАРУБІЖНИЙ ДОСВІД КОРОЛІВСТВА ШВЕЦІї У ПОБУДОВІ СИСТЕМИ УПРАВЛІННЯ ВИЩИМИ НАВЧАЛЬНИМИ ЗАКЛАДАМИ МИСТЕЦЬКОЇ ОСВІТИ
}

Анотація. Актуальність. Забезпечення якості в європейській системі управління мистецькою вищою освітою перебуває у стані динамічних змін, що зумовлено інтенсивними євроінтеграційними освітніми процесами. У більшості країн Свропейського простору засновано установи, відповідальні за забезпечення якості в галузі вищої освіти, в тому числі й мистецької. Європейське бачення демократії зумовило зростання рівності у забезпеченні освітою, підвищення рівня освіченості населення, кількісне збільшення навчальних закладів. Галопуючий технічний розвиток впливає на розгалуження та варіативність професійного діапазону. Це зумовлює повторне включення великої кількості людей до сфери освіти, яка набуде тенденції постійного поширення і оновлення. Mета і методи. Мета статті полягає у виявленні та узагальненні основних тенденцій і принципів формування системи управління вищими навчальними закладами, зокрема мистецького спрямування, Королівства Швеції. За допомогою порівняльного аналізу проведена оцінка структури системи управління та іiі елементів. Використано методи просторового аналізу і синтезу. Результати. Полягають у виокремленні передумов формування структури системи управління та іiі елементів, особливостей і закономірностей їх функціонування. Акцентовано увагу на можливості застосування зарубіжного досвіду у вітчизняній системі управління. Висновки та обговорення. Наукова новизна полягає у виокремленні ключових тенденцій та принципів формування й функціонування системи управління вищими навчальними закладами Королівства Швеції. Практичне значення полягає у подальшій розробці на основі проведеного дослідження стратегічних напрямів щодо імплементації даного досвіду в українську систему управління, які зможуть забезпечити покращення рейтингових позицій вітчизняних вищих навчальних закладів у міжнародному вимірі.

Ключові слова: зарубіжний досвід, ринок послуг вищої освіти, система управління вищою освітою, университет, мистецька освіта, інтеграція, міжнародна співпраця.

Фейчер Оксана Александровна, аспирант, Национальная академия руководящих кадров культуры и искусств, Киев, Украина, feicher@i.ua

Зарубежный опыт Королевства Швеции в построении системы управления высшими учебными заведениями в области искусства 
Аннотация. Актуальность. Обеспечение качества в европейской системе управления высшим образованием в области искусства всегда находилось в состоянии динамических изменений. В большинстве стран Европейского пространства основаны учреждения, ответственные за обеспечение качества высшего образования. Европейское видение демократии обусловило повышение уровня образованности населения и количественное увеличение учебных заведений. Сверхбыстрое техническое развитие влияет на разветвление и вариативность профессионального диапазона. Это обусловливает необходимость повторного включения большого количества людей в сферу образования, которая будет иметь тенденции постоянного распространения и обновления. Цель и методы. Цель статьи заключается в выявлении и обобщении основных тенденций и принципов формирования системы управления высшими учебными заведениями, в частности в области искусства, Королевства Швеции. С помощью сравнительного анализа проведена оценка системы управления и ее элементов. Использованы методы пространственного анализа и синтеза. Результатыл. Заключаются в выделении предпосылок формирования структуры системы управления и ее элементов, особенностей и закономерностей их функционирования. Акцентировано внимание на возможности применения зарубежного опыта в отечественной системе управления образованием. Выводы и обсуждение. Научная новизна заключается в выделении ключевых тенденций и принципов формирования и функционирования системы управления высшими учебными заведениями Королевства Швеции. Практическое значение состоит в дальнейшей разработке на основе проведенного исследования стратегических направлений по имплементации опыта в украинскую систему управления, которые смогут обеспечить улучшение рейтинговых позиций отечественных высших учебных заведений в международном измерении.

Ключевые слова: зарубежный опыт, рынок услуг высшего образования, система управления высшим образованием, университет, образование в области искусства, интеграция, международное сотрудничество.

Feicher Oksana, Graduate Student, National Academy of Managerial Staff of Culture and Arts, Kiev, Ukraine, feicher@i.ua

Foreign experience of the Kingdom of Sweden in construction management systems of higher educational institutions of arts education

Abstract. Actuality. Quality assurance in the European system of management of arts higher education has always been in a state of dynamic changes and it has been conditioned by intensive eurointegration educational processes. In most countries of the European Space, institutions are responsible for quality assurance in the field of higher education, including artistic ones, which have been based. This situation compels the re-inclusion of a large number of people in the education sector. Education will have tendencies of constant distribution and renewal throughout the life of the individual. Purpose and methods. The aim of the article is to reveal and summarize the main trends and principles of the formation of the management system of higher educational institutions, in particular the artistic direction, the Kingdom of Sweden. With the help of a comparative analysis, we have carried out an assessment of the structure of the control system and its individual elements. Methods of spatial analysis and synthesis have actively been used. Results. Conclude in the 
allocation of the prerequisites for the formation the structure of the management system and its elements, features and regularities of their functioning. Conclusions and discussion. The scientific novelty consists in distinguishing the key trends and principles of the formation and functioning of the management system of the higher educational institutions of the Kingdom of Sweden. It is of practical importance to further develop, on the basis of the study, strategic directions on the implementation of this experience in the Ukrainian management system, which will be able to improve the rating positions of domestic higher education institutions in an international dimension.

Keywords: foreign experience, services market of higher educations, higher education management system, university, art education, integration, international cooperation.

\section{1. Актуальність проблеми Actuality of problem}

Мистецька освіта як всесвітньо визнаний компонент неперервної освіти є доволі новим для української освітньої думки у контексті як змісту категорії, так і методології та практики щодо організації й управління нею. Це детерміновано дією чинників, які ускладнюють виокремлення категорії «мистецька освіта» у вітчизняних дослідженнях. У вітчизняній нормативно-правовій базі сфери освіти дана категорія не $є$ регламентованою. Розрізнений досвід організації мистецької освіти не $\epsilon$ системним, тому досить складно визначати його закономірності і тенденції (Обгрунтування... Мартинишин та ін., 2017; Теліжко та ін., 2016). Це визначає актуальність наукових досліджень щодо сутності та змісту мистецької освіти, зокрема на основі компаративного аналізу досвіду скандинавських країн, чиї здобутки щодо організації такої освіти характеризують іiі подальший розвиток.

Стан вивчення проблеми. Проблема імплементації зарубіжного досвіду системи управління вищими навчальними закладами останнім часом набуває все нового забарвлення і більшої актуальності, оскільки відрив вітчизняних вищих навчальних закладів від світових лідерів $€$ доволі суттєвим. Оскільки Швеція є одним із таких лідерів, пропонуємо зосередити увагу саме на вивченні ії досвіду щодо формування системи управління вищими навчальними закладами. Дослідження з даної проблематики було здійснено як вітчизняними, так і зарубіжними науковцями. Так, О. Цюк (2016) глибинно розкрила історію реформування системи вищої освіти та національної системи забезпечення ії̈ якості в Королівстві Швеція. О. Шмотіна (2016) в свою чергу здійснила детальний аналіз шведської моделі системи освіти, де послідовно надала характеристику дошкільному, шкільному, гімназійному та університетському рівням освітньої системи, особливо зосередила увагу на засобах та формі атестації учнів і студентів. Слід наголосити, що дана проб- 
лема широко досліджена саме шведськими науковцями, оскільки удосконалення системи управління вітчизняною системою вищої освіти $\epsilon$ стратегічним завданням усієї шведської наукової спільноти. Повними та вичерпними $є$ доробки наукової спільноти Ради університетської та вищої освіти Швеції (Universitets och högskolerådet, 2017), які систематично згрупували усі рівні вищої освіти у Швеції та етапи їхнього формування і розвитку.

Однак загальним недоліком більшості вітчизняних наукових праць виступає відсутність розробки чіткого плану дій щодо імплементації даного досвіду в українське освітнє середовище, оскільки найчастіше розглядаються питання лише аналізу зарубіжного досвіду щодо формування системи управління вищими навчальними закладами та його провідних тенденцій.

Невирімені питання. Як свідчить аналіз публікацій, у більшості наявних досліджень мало уваги приділяється розробці шляхів використання зарубіжного досвіду у загальних стратегіях розвитку ВНЗ мистецького спрямування і вітчизняної системи мистецької вищої освіти загалом. Більшість вітчизняних дослідників найчастіше висувають пропозиції щодо реалізації поширених зарубіжних доробків, які є загальновідомими, і оминають конкретизацію заходів зарубіжних партнерів щодо модернізації та апгрейду системи управління вищими навчальними закладами мистецької освіти.

Досвід скандинавських країн із вирішення даної проблематики неповно досліджено і проаналізовано, хоча саме ці країни демонструють сталу тенденцію щодо зростання економічної ефективності з багатьох напрямків. Саме інтеграція досвіду країн із провідними позиціями щодо економічного розвитку у загальносвітовому рейтингу дасть змогу вітчизняній системі вищої освіти ефективно змінюватись і забезпечити динамічний розвиток у подальшому.

\section{2. Мета і методи дослідження Purpose and research methods}

Мета статті - виявити, узагальнити та виокремити основні тенденції та принципи формування системи управління вищими навчальними закладами, зокрема мистецького спрямування, Королівства Швеції.

Методологічною основою дослідження є емпіричний і системний підходи, згідно з якими всі процеси, що притаманні та характеризують систему управління вищими навчальними закладами, досліджено у взаємозв'язку і здійснено прогнозування їхнього розвитку.

Методи дослідження. Під час проведення дослідження було застосовано методи порівняльного аналізу, синтезу, узагальнення та сис- 
темний підхід. Метод порівняльного аналізу дав можливість визначити місце шведської системи вищої освіти у міжнародному просторі. За допомогою методу узагальнення здійснено опис кожного освітнього рівня та його елементів. Завдяки синтезу встановлено взаємозв'язок між усіма складовими системи управління. Використання системного підходу дало можливість структурувати етапи дослідження та дійти до змістовних висновків щодо проведеного дослідження.

Інформаційну базу дослідження становлять результати аналізу публікацій вітчизняних та зарубіжних науковців щодо даної проблематики, власний досвід навчання у шведських закладах освіти, аналітичні звіти Світового рейтингу університетів та Ради університетської та вищої освіти Швеції.

\section{3. Результати дослідження Research results}

Загальний огляд шведської системи освіти пропонуємо розпочати 3 аналізу процесу формування системи рівнів освіти. Так, із ХІІІ ст. у Швеції існували церковні, монастирські та міські школи. У 1477 р. був заснований найстаріший у Скандинавії Уппсальський університет, у якому в 1630 р. навчалося 1000 студентів. У 1623 р. утворено першу в Швеції гімназію. У 1842 р. рішенням шведського парламенту - Риксдагу були відкриті безкоштовні чотирирічні так звані «народні школи», навчання в яких було обов'язковим. Саме це дало поштовх щодо зникнення в Швеції неграмотності як соціального явища. Із 1882 р. народні школи стали 6-річними, у 1936 р. 7-річними, у 1950-х рр. - 8-річними. Із 1972 р. у Швеції обов’язковою є 9-річна шкільна освіта (Шмотіна, 2016).

Послідовний динамічний розвиток освітньої системи забезпечив Швеції сьогодні провідні місця у світових освітніх рейтингах (табл. 1, 2). Так, відповідно до Світового рейтингу університетів, на початок 2018 p. серед найкращих 500 вузів (QS World University Rankings) вісім позицій посідають шведські університети: лідерами є Лундський університет (78-а позиція) та найстаріший шведський Уппсальський університет (112-а позиція) (British Quacquarelli Symonds, 2018).

Пропонуємо розглянути цілісно структуру сучасної шведської системи освіти, яка складається з чотирьох рівнів:

- перший рівень - nidготовча школа (förskola), iï називають «dagis», що відповідає вітчизняному поняттю «дитячий садок»;

- другий рівень - школа (skolan), формально в ній дев'ять класів. Обов'язковим $є$ навчання з першого по дев'ятий клас. Переважна більшість шкіл є муніципальними, хоча існує також незначна кількість вільних шкіл, частина 3 яких пов'язана з альтернативною педагогікою (валь- 
дорфською, Монтессорі), а частина - із релігійними громадами «вільних церков». Усі школи щодо стандартів і вимог відповідають загальнодержавному закону про освіту. Інтегрована середня школа вищого ступеня передбачає близько 26 варіантів вибору програми за трьома основними напрямками: однорічні професійно орієнтовані, дворічні технічні і трирічні академічні програми;

Табл. 1. Місце шведських вищих навчальних закладів у Світовому рейтингу університетів на початок 2018 р. Tab. 1. The place of the Swedish higher education institutions in the World University Ranking at the beginning $2018 \mathrm{yr}$.

\begin{tabular}{|l|c|c|c|c|c|c|}
\hline \multirow{2}{*}{\begin{tabular}{|} 
Назва \\
університету
\end{tabular}} & \multicolumn{3}{|c|}{ Позиція у рейтингу } & \multirow{2}{*}{ Статус } & \multicolumn{2}{|c|}{ Кількість } \\
\cline { 3 - 4 } & 2012 & 2015 & 2018 & ВНЗ & студентів & $\begin{array}{c}\text { співро- } \\
\text { бітників }\end{array}$ \\
\hline $\begin{array}{l}\text { Лундський } \\
\text { університет }\end{array}$ & 71 & 60 & 78 & $\begin{array}{c}\text { Публіч- } \\
\text { ний }\end{array}$ & 27786 & 3031 \\
\hline $\begin{array}{l}\text { Королівський } \\
\text { технологічний } \\
\text { інститут КТН }\end{array}$ & 142 & 110 & 98 & $\begin{array}{c}\text { Публіч- } \\
\text { ний }\end{array}$ & 12658 & 1500 \\
\hline $\begin{array}{l}\text { Уппсальський } \\
\text { університет }\end{array}$ & 81 & 81 & 112 & $\begin{array}{c}\text { Публіч- } \\
\text { ний }\end{array}$ & 25371 & 2567 \\
\hline $\begin{array}{l}\text { Чалмерський } \\
\text { університет } \\
\text { технологій }\end{array}$ & 223 & 175 & 133 & $\begin{array}{c}\text { Приват- } \\
\text { ний }\end{array}$ & 9257 & 1077 \\
\hline $\begin{array}{l}\text { Стокгольмський } \\
\text { університет }\end{array}$ & 171 & 182 & 195 & $\begin{array}{c}\text { Публіч- } \\
\text { ний }\end{array}$ & 28281 & 2154 \\
\hline $\begin{array}{l}\text { Гетеборзький } \\
\text { університет }\end{array}$ & 193 & 206 & 283 & $\begin{array}{c}\text { Публіч- } \\
\text { ний }\end{array}$ & 26630 & 2683 \\
\hline $\begin{array}{l}\text { Університет } \\
\text { м. Лінчопінг }\end{array}$ & 340 & 283 & 287 & $\begin{array}{c}\text { Публіч- } \\
\text { ний }\end{array}$ & 18148 & 2310 \\
\hline $\begin{array}{l}\text { Університет } \\
\text { Умео }\end{array}$ & 297 & 267 & 338 & $\begin{array}{c}\text { Публіч- } \\
\text { ний }\end{array}$ & 13980 & 1960 \\
\hline
\end{tabular}

Джерело: розроблено на основі (British Quacquarelli Symonds, 2018)

Source: developed on the basis of (British Quacquarelli Symonds, 2018)

- третій рівень - гімназія (gymпаsium), яка є спеціалізованою. Прийом до гімназії здійснюється за шкільним атестатом. Учень може подавати документи відразу в кілька гімназій, однак остаточний прохідний бал оголошується після підрахунку заяв із балами. Навчання в гімназії не $є$ обов'язковим. Існують різні типи гімназій, частина з них - профільні (наприклад, перукарі), і тому за предметами, що вивчаються, не орієнтовані на вступ до вищих навчальних закладів. Цікавим $\epsilon$ те, що у гімназії в кожного учня $є$ індивідуальний план; 
Табл. 2. Формування оцінки ефективності функціонування ВНЗ Швеції за Світовим рейтингом університетів на початок 2018 р.

$T a b$. 2. Formation of assessment of the efficiency in the functioning of the University of Sweden at the World University Ranking at the beginning $2018 \mathrm{yr}$.

\begin{tabular}{|c|c|c|c|c|c|c|c|}
\hline $\begin{array}{c}\text { Назва } \\
\text { університету }\end{array}$ & 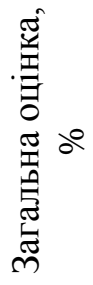 & 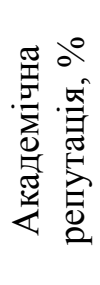 & 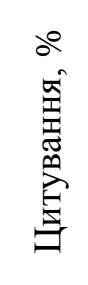 & 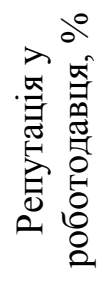 & 己 & 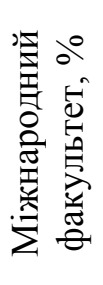 & 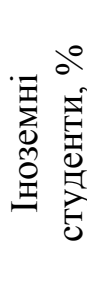 \\
\hline $\begin{array}{l}\text { Лундський } \\
\text { університет }\end{array}$ & 68,5 & 80 & 51,8 & 71,8 & 53,7 & 88,3 & 73,8 \\
\hline $\begin{array}{l}\text { Королівський } \\
\text { технологічний } \\
\text { інститут }\end{array}$ & 64,7 & 57,2 & 70 & 87 & 62,5 & 88,1 & 42 \\
\hline $\begin{array}{l}\text { Уппсальський } \\
\text { університет }\end{array}$ & 61,4 & 75,7 & 56,5 & 49,4 & 46,2 & 46,7 & 64,1 \\
\hline $\begin{array}{l}\text { Чалмерський } \\
\text { університет } \\
\text { технологій }\end{array}$ & 57,1 & 42,1 & 70,3 & 75,7 & 60,5 & 84,9 & 44,2 \\
\hline $\begin{array}{l}\text { Стокгольмський } \\
\text { університет }\end{array}$ & 48,1 & 65,8 & 49,2 & - & - & 64,3 & - \\
\hline $\begin{array}{l}\text { Гетеборзький } \\
\text { університет }\end{array}$ & 38,6 & 43,5 & 32,9 & - & 45,8 & 39,5 & 33,2 \\
\hline $\begin{array}{l}\text { Університет } \\
\text { м. Лінчопінг }\end{array}$ & 38,4 & 27,3 & 30,4 & 44,4 & 70,2 & 39 & - \\
\hline $\begin{array}{l}\text { Університет } \\
\text { Умео }\end{array}$ & 34,8 & - & 23,4 & - & 79,9 & 29 & - \\
\hline
\end{tabular}

Джерело: розроблено на основі (British Quacquarelli Symonds, 2018)

Source: developed on the basis of (British Quacquarelli Symonds, 2018)

- четвертий рівень - вищі навчальні заклади, до них належать університети та вищі школи (högskolan), навчання в яких $є$ безкоштовним. Останнім часом кількість студентів у системі вищої освіти значно зросла. Із 1991 р. кількість місць в університетах і університетських коледжах збільшилася приблизно на $30 \%$. Прийом нових студентів становить щорічно близько 50 тис. осіб. Із 1950-х рр. шведська система вищої освіти змінювалася кілька разів. Останню масштабну реформу було проведено у 1991 р. $з$ метою надання системі в цілому та окремим навчальним закладам більшої самостійності (Universitets och högskolerådet, 2017).

Звернемо увагу на статистичні дослідження Ради університетської та вищої освіти Швеції (Universitets och högskolerådet, 2017), яка відповідає на різні питання щодо системи освіти, розвитку та взаємодії учнів 
у школі, професійний розвиток здобувачів освіти. Так, за даними Ради, щороку у Швеції навчаються близько 357 тис. осіб. Для здобуття рівня кандидата наук $(\mathrm{PhD})$ та магістра доступні багато програм, розраховані на понад 4 тис. місць. Також чимало програм на рівень кандидата наук та магістра доступні з навчанням англійською мовою (понад 7 тис. місць). Відсоток населення Швеції у віці до 30-34 років із принаймні двома роками вищої освіти становить 47,5 \%. Найвищу суму, яку студент може отримати за повний робочий день щорічно із студентською підтримкою, становить 90,3 тис. шведських крон, тобто близько 10 тис. євро.

Для шведської системи вищої освіти сьогодні характерне поступове зростання питомої ваги іноземних студентів, кількість яких у 2017 p. становила понад 13 тис. осіб. Сучасною інноваційною тенденцією в системі освіти $є$ зростання кількості студентів, які навчаються дистанційно (68 тис. осіб).

Загалом система вищої освіти Швеції включає 24 університети та університетські коледжі, плата за навчання в яких для громадян країни відсутня, а для іноземних студентів встановлюється кожним вищим навчальним закладом самостійно і варіюється від 7 до 17 тис. євро за навчальний рік. Так, за 2 роки (120 кредитів) студент може отримати сертифікат слухача курсів, за 3 роки (180 кредитів) - диплом бакалавра. Після бакалаврату студентові необхідно додатково прослухати 60 кредитів загальною тривалістю 1 рік для отримання диплому магістра 1-го рівня (Magister) або 120 кредитів загальною тривалістю 2 роки для отримання диплому магістра 2-го рівня (Master) (Högskolan, 2017).

Одне із ключових завдань шведської системи вищої освіти - виключити конкуренцію між студентами. Система навчання побудована відповідно до принципу студентоцентричності, а спілкування між студентами і викладачами має виключно неформальний характер, що дає змогу глибше зосередитися на процесі навчання. Ця освіта та структура ступенів була запроваджена 1 січня 2007 р. та $є$ частиною зусиль Швеції щодо адаптації вищої освіти до загальноєвропейських стандартів та Болонського процесу (Universitets kanslersämbetet, 2017).

На наступному етапі дослідження зосередимо увагу на градації шведської системи вищої освіти та її кваліфікаційних рівнів, оскільки існує певний поділ на рівні: базовий (grundnivå), удосконалений (avancerad nivå) та третій найвищий (forskarnivå) рівні. Вони $є$ взаємозалежними та взаємодоповнюючими. Освіта у шведських вищих навчальних закладах побудована на основі наукових та художніх досягнень й апробованого досвіду.

Із 2015 р. у Швеції існує Рада кваліфікацій (SeQF), яка охоплює всі рівні освіти та заснована на Європейській системі кваліфікацій для 
навчання протягом життя (EQF-LLL). Iз SeQF результати навчання можуть бути візуалізовані незалежно від того, як вони набуваються. Це полегшує порівняння кваліфікацій із навчання та практичних навичок як на національному, так і на міжнародному рівні. В свою чергу Національна довідкова система для дипломів представляє огляд Шведської системи вищої освіти (НКФ).

Швеція реконструювала вищу освіту через Рамку Кваліфікацій Європейського простору вищої освіти, тому результати навчання чітко передбачають, що студенти вивчатимуть і які знання вони отримають. Результати навчання мають запобігти неузгодженості між змістом освіти та потребами студентів, оскільки вони включають три частини: очікувані результати навчання й екзамен; досягнуті результати навчання; досвід і вплив студентів (Цюк, 2016).

Варто врахувати, що вищі навчальні заклади проводять самооцінку на основі загальних керівних принципів для самооцінки в системі оцінки якості Шведського національного агентства з вищої освіти (University, 2018). Дисертації студентів як результати навчання оцінюються зовнішніми експертами, які проводять відвідування сайту. Саме це забезпечує незалежне об'єктивне оцінювання наукових досягнень слухачів різних освітніх рівнів підготовки. Система забезпечення якості вищої освіти Швеції використала досвід національних систем забезпечення якості інших країн, що позитивно позначилося на її становленні.

Слід виокремити також спеціальну державну установу Канцелярію університетів (Universitets kanslersämbetet (UKÄ)), до повноважень якої входять три основні напрямки: забезпечення якості системи університетської освіти та вивчення сучасної системи іспитів; юридичний нагляд та супровід системи вищої освіти; аналіз ефективності, подальшого моніторингу, екологічного аналізу та статистичної відповідальності за сектор вищої освіти (Universitets kanslersämbetet, 2017)

Канцелярія університетів (UKÄ) проводить щорічно глибинні грунтовні дослідження щодо аналізу динаміки якості вищої освіти, оскільки як для студентів, так і для роботодавців та суспільства важливо, щоб уся університетська освіта в Швеції була високоякісною. Останнім часом важливість роботи Канцелярії університетів (UKÄ) все більше зростає, оскільки уряд вважає, що потреба в оцінці та подальшій апробації шведських досліджень повинна бути розроблена у відповідності до його цілей та подій у зовнішньому світі.

Щодо дослідницької політики університетів, то уряд вбачає необхідність іï поглиблення на десятирічну перспективу, приділяючи особливу увагу інвестиціям у 2018-2020 pр. Метою дослідницької політики є реалізація Швеції як провідної країни знань та однієї з провідних сві- 
тових дослідницьких й інноваційних країн. Так, уряд пропонує підвищити базове фінансування університетів на 1,3 млрд євро до 2020 р., оскільки це дасть змогу підвищити якість і забезпечити більше можливостей для проведення досліджень.

Важливим аспектом шведської культури є дотримання загальноприйнятих законів гуманістичного характеру, тому це чітко простежується і у побудові системи управління вищими навчальними закладами. Так, на розгляд уряду представлено законопроект про нову національну мету із гендерної рівності: до 2030 р. половина набору усіх професорсько-викладацьких послуг має бути забезпечена жінками. До прикладу, у 2016 р. частка професорів-жінок у Швеції становила близько $25 \%$ (Forsknings, 2016).

Здійснивши глибинний різнобічний аналіз становлення, побудови, загальних принципів функціонування і оцінки якості діяльності системи освіти у Швеції, розглянемо особливості побудови системи вищої освіти мистецького спрямування. Так, у Швеції мистецтво визначають відповідно як творчу діяльність, що стосується декоративних, емоційних або красномовних виразів, або результат такої діяльності. Концепція мистецтва часто включає образотворче мистецтво, мистецтво та ремесла, архітектуру, скульптуру та музику. Існує значна кількість різноманітних підходів щодо вибору напряму освіти в мистецтві. Так, у студентів є можливість здобути освіту мультиплікатора, скульптора, графіка або художника.

Щодо мистецького виховання на різних освітніх рівнях, то слід відзначити, що освіта мистецького спрямування надається у більшості шкіл. Так, Художня школа Фалькенберга (Falkenbergs konstskola) (Utbildningar i Falkenbergs..., 2018) дає змогу вивчення мистецьких фондів у післягалузевій художній школі. Це дає достатню основу для подальшого навчання в коледжі мистецтв і дизайну. Однорічні курси підготовки до коледжу мають 12 місць денної форми навчання. Дана школа також надає можливість навчатися дистанційно і має 17-річний досвід у цьому. Зв'язок в основному здійснюється за допомогою освітньої платформи через інтернет та веб-камеру.

Однак для отримання вченого ступеня з мистецтва слід звернутися до тих університетів, при яких функціонують школи мистецтв (Стокгольм, Гетеборг, Умео та Мальме). Існує також спеціальна освіта для професійних художників у галузі графіки, скульптури, цифрових медіа, відео або монументальних технік.

Професійну освіту в мистецтві також надають приватні освітні установи, однак у Швеції немає державного органу, який регулює i контролює ці програми. Тому для абітурієнта важливо заздалегідь знати, 
який ступінь отримати і чи відповідає він національним або міжнародним стандартам. Також слід врахувати, що професійне навчання може мати досить високу вартість, однак вона може варіюватися залежно від обраної програми.

У шведських державних вищих навчальних закладах представлено досить розгалужений спектр освітніх послуг у галузі мистецтва. Мистецькій освіті в народній гімназії часто присвячують окремі загальні та підготовчі курси. Так, наприклад, Культурама (Kulturama) (Utbildningar i Kulturama, 2018) у Стокгольмі дає можливість студентові обрати денну або дистанційну форму навчання у галузі музики, музичного виробництва, вокалу, опери, танцю, театральної майстерності, музичного, фотота кіномистецтва, дизайну.

Це єдина вища школа у Північному регіоні Швеції, яка поєднала усі мистецькі дисципліни разом в одному навчальному закладі. Цей навчальний заклад, що існує близько 40 років, - найбільша школа естетичного виховання у регіоні. У Культурамі є курси танцю, музики, театрального мистецтва, співу, дизайну, фото- та відеомистецтва, музичного виробництва.

Всі програми денної форми навчання перебувають під державним наглядом. Загалом у 2018 р. приблизно 360 студентів відвідують освітні програми культури. Культурама спеціалізується на розробці і впровадженні освітніх програм естетичного спрямування та спирається на ідею визначення освіти як головної рушійної сили, що забезпечує можливість спостерігати прогресивний розвиток студентів як окремих індивідів суспільства.

Інший тип підготовчої освіти - це навчання у школі для дорослих Комвукс (Komvux), яка реалізує кілька різних курсів мистецтва. Для того, щоб ознайомитись із можливостями здобування мистецької освіти, слід звернутися до відділу освіти для дорослих у відповідному місті (kommuna).

Стрімко зростає у Швеції послуга дистанційного навчання. Так, якщо у студента немає можливості переїхати до міста, де базується вищий навчальний заклад, він може скористатися послугою дистанційного навчання в мистецтві, яка будується так само, як і аудиторне навчання із відвідуванням навчального закладу.

Оскільки мистецтво - це вже світова індустрія, то існує велика кількість можливостей для здобуття вищої світи у сфері мистецтва за кордоном. Останнім часом ця тенденція серед шведської молоді набирає значної популярності, оскільки, крім мистецької освіти, студенти мають можливість отримати нові мовні навички, поглибити свою комунікативність та освоїти нові культури. 


\section{4. Висновки та обговорення результатів Conclusions and discussion of results}

Результати проведених досліджень дають змогу дійти до наступних висновків:

1. Система вищої освіти Королівства Швеції будується на науці, перевіреному досвіді, дослідженнях та творчому розвитку. Відповідно до впровадженої системи управління вищі навчальні заклади повинні взаємодіяти з громадою, оточуючим середовищем і надавати інформацію про свою діяльність. У сучасних умовах взаємодія із суспільством $\epsilon$ важливим обов'язком вищих навчальних закладів, суттєвою інтегральною частиною їхньої діяльності. Навчальний процес у системі вищої освіти будується в Швеції відповідно до вимог Болонського процесу.

2. Головна роль у вищій освіті Швеції відводиться університетам і університетським коледжам. Шведські університети мають високу конкурентоздатність, що пояснюється високим рівнем якості навчання. Вони відповідають на виклики сьогодення, характеризуються динамізмом i гнучкістю у прийнятті необхідних освітніх рішень. У системі вищої освіті країни існують відкриті, демократичні стосунки між студентами і викладачами, в яких цінується особиста ініціатива та творче мислення.

3. Держава визначає структуру системи вищої освіти, регламентує види ступенів, які присвоюються, здійснює контроль за ії якістю. Державні кошти для досліджень розподіляються між університетами за індивідуальними програмами. Ресурси для наукових досліджень можуть варіюватись і включати внески спеціальних фондів та організацій, міжнародні інвестиційні проекти.

4. Система мистецьких вищих навчальних закладів має досить розгалужену структуру. Саме мистецтво визначено відповідно як творчу діяльність, що стосується декоративних, емоційних чи красномовних виразів, або як результат такої діяльності. Концепція мистецтва часто включає образотворче мистецтво, мистецтво та ремесла, архітектуру, скульптуру та музику. Існують як окремі мистецькі школи, так і університети даного спрямування. Інноваційно новим типом мистецької освіти $є$ навчання у школі для дорослих Комвукс. Тенденцію щодо зростання демонструють послуги дистанційного навчання.

Наукова новизна одержаних результатів полягає у тому, що проведений глибинний аналіз системи управління вищими навчальними закладами дав змогу виокремити ії сильні та слабкі сторони, інноваційні напрями розвитку та сучасні тенденції, які задовольняють вимоги часу.

Практичне значення одержаних результатів виявляється в можливостях безпосередньо порівняти вітчизняні реалії із зарубіжними доробками та розробити спеціальні заходи щодо усунення виявлених недоліків. 
Перспективи подальших наукових розвідок полягають у розробці чіткого плану дій стосовно до імплементації зарубіжного досвіду провідних країн світу щодо формування системи управління вищими навчальними закладами мистецької освіти для забезпечення покращення іміджу України у світовій спільноті.

\section{Література}

Обгрунтування парадигми менеджмент-освіти у соціокультурній сфері : монографія. За ред. Я. М. Мартинишина. Біла Церква : Видавець О. В. Пшонківський, 2017. 509 с.

Теліженко О. М., Лук'янихін В. О., Байстрюченко Н. О., Проектно-орієнтований підхід до організації навчального процессу. Вісник НТУ «ХПIџ». Сер.: Стратегічне управління, управління портфелями, програмами та проектами. 2016. № 1 (1173). С. 30-35.

DOI: https://doi.org/10.20998/2413-3000.2016.1173.6

Цюк О. Розвиток системи забезпечення якості вищої освіти Швеції. Педагогіка і психологія професійної освіти. 2016. № 2. С. 169-178.

Шмотіна О. В. Шведська модель освіти. Науковий вісник МДУ ім. В.О. Сухомлинського. 2016. Вип. 1.33. С. 125-127.

Forsknings propositionen. URL: http://www.uka.se/fakta-om-hogskolan/forskning/forskningspropositionen-2016.html (дата звернення : 09.01.18).

Högskolan under 2000-talet. URL: http://www.uka.se/fakta-om-hogskolan/ den-svenska-hogskolans-historia/hogskolan-under-2000-talet.html (дата звернення : 02.03.18).

Högskolestudier i Sverige. Universitets och högskolerådet : Hylte tryck, 2017. $32 \mathrm{p}$.

Universitets kanslersämbetet (UKÄ)-2017. URL: http://www.regeringen.se/ myndigheter-med-flera/universitetskanslersambetet-uka/ (дата звернення : 09.01.18).

Universitets och högskolerådet. URL: https://www.studera.nu/ (дата звернення : 09.01.18).

University admissions i Sverige-2018. URL: https://www.university admis sions.se/intl/search?period=HT_2018\&freeText=Konstutst\%C3\%A4ll ning\&semesterPart=0 (дата звернення : 09.01.18).

Utbildningar i Falkenbergs konstskola. URL: http://falkenbergskonstskola.se/ category/12/om-skolan (дата звернення : 09.01.18).

Utbildningar i Kulturama. URL: http://www.kulturama.se/Utbildningar/ (дата звернення : 09.01.18).

World University Rankings. British Quacquarelli Symonds. 2018. URL: https:// www.topuniversities. com/qs-world-university-rankings (дата звернення : 09.01.18). 


\section{References}

Forsknings propositionen [Research Bill] (2017). Retrieved from http://www. uka.se/fakta-om-hogskolan/forskning/ forskningspropositionen-2016.html (in Sv.).

Högskolan under 2000-talet [University in the 21st century] (2017). Retrieved from http://www.uka.se/fakta-om-hogskolan/den-svenska-hogskolans- his toria/hogs kolan-under-2000-talet.html (in Sv.).

Högskolestudier i Sverige [University studies in Sweden published by the University and Higher Education Council] (2017). Universitets och högskolerådet: Hylte tryck (in Sv.).

Martynyshyn, Y. M. (Ed.). (2017). Obgruntuvannia paradyhmy menedzhmentosvity u sotsiokulturnij sferi: monohrafiia [Substantiation of the paradigm of management education in the socio-cultural sphere: monograph]. Bila Tserkva: Vydavets O. V. Pshonkivskyj (in Ukr.).

Shmotina, O. V. (2016). Shvedska model osvity [Swedish Model of Education]. Naukovyj visnyk MDU im. V.O. Sukhomlynskoho [Scientific Herald MSU them. VO Sukhomlinskoho], 1.33, 125-127 (in Ukr.).

Telizhenko, O. M., Lukyanykhin, V. O., \& Baystryuchenko, N. O. (2016). Proektno-oriyentovanyj pidxid do organizaciyi navchalnogo procesu [Project-oriented approach to the educational process]. Visnyk NTU «KhPI». Ser.: Stratehichne upravlinnya, upravlinnya portfelyamy, prohramamy ta proektamy [Bulletin of National Technical University "KhPI". Ser.: Strategic management, portfolio, program and project management], 1 (1173), 30-35. DOI: https://doi.org/10.20998/2413-3000.2016.1173.6 (in Ukr.).

Tsiuk, O. (2016). Rozvytok systemy zabezpechennia iakosti vyschoi osvity Shvetsii [Development of the quality assurance system of higher education in Sweden]. Pedahohika i psykholohiia profesijnoi osvity [Pedagogy and psychology of professional education], 2, 169-178 (in Ukr.).

Universitets kanslersämbetet (UKÄ) [University Chancellors Office] (2017). Retrieved from http://www.regeringen.se/ myndigheter-med-flera/univer sitets kanslersambetet-uka/ (in Sv.).

Universitets och högskolerådet [University and Higher Education Council] (2018). Retrieved from https://www.studera.nu/ (in Sv.).

Universityadmissions i Sverige [University admissions in Sweden] (2018). Retrieved from https://www.universityadmissions.se/int//search?period= HT_ 2018 \&freeText=Konstutst\%C3\%A4llning\&semesterPart=0 (in Sv.).

Utbildningar i Falkenbergs konstskola [Education at Falkenberg Art School] (2018). Retrieved from http://falkenbergskonstskola.se/category/12/omskolan (in Sv.).

Utbildningar i Kulturama [Education at Kulturama] (2018). Retrieved from http://www.kulturama.se/Utbildningar/ (in Sv.).

World University Rankings (2018). British Quacquarelli Symonds. Retrieved from https://www.topuniversities.com/qs-world-university-rankings. 